\title{
Crop contamination and spring wheat yield depending on the systems of pre-sowing tillage
}

\author{
Albert Kuzminykh*, Sergey Novoselov, Galina Pashkova \\ Mari state university, Yoshkar-Ola, Russia
}

\begin{abstract}
This research has been conducted to study the influence of pre-sowing tillage methods on the crop contamination and spring wheat yield. It has been established that the use of continuous cultivation in the system of pre-sowing tillage contributes to the reduction of crop contamination by 21.2-45.1\%. That allowed obtaining a higher grain yield of 2.48-2.54 t/ha with a protein content of $11.74-11.80 \%$. The gluten was $25.0-25.4 \%$ of the first quality group and with a vitreous content of 53.2-54.4\%.
\end{abstract}

\section{Introduction}

In Russia, spring breads characterized by simpler agricultural technologies and a wide species of the composition are given the first place in gross grain harvest. The leading crop among spring crops is considered to be spring wheat. The grain of spring wheat is the main food of most people of the world. It contains nutrients - proteins, carbohydrates, fats, vitamins and minerals - that are essential for people. Spring wheat grain and cereals are mainly used to produce flour used in the baking and confectionery industries. Forage grain of spring wheat and waste from the flour milling industry are used for feed for agricultural animals and poultry [1].

In the complex of agrotechnical measures that ensure high yields of agricultural crops, tillage plays a major role. The physical, agrochemical and biological indicators of soil fertility, which largely determine the size and quality of the future crop, depend on the tillage and the quality of its implementation. According to many researchers, the yield of agricultural crops depends on the method and quality of tillage by $25 \%$ [2-8].

In modern agricultural systems, resource conservation is one of the most important problems. Tillage is a costly, labor-intensive and energy-intensive activity, and many farmers are currently forced to search for and apply new low-cost agricultural technologies, which often unnecessarily simplify tillage systems, while reducing the overall crop of agriculture. This negatively affects the phytosanitary condition of agrocenosis, the yield and quality of agricultural products. Therefore, the search for optimal tillage systems aimed at improving soil fertility, the phytosanitary state of agrocenosis and, as a result, obtaining high stable yields of agricultural crops have always been and remain relevant [9-10].

\section{The purpose and methodology of research}

In 2019 and 2020, we conducted research at the experimental field of Mari State University. The aim of the study is to analyze the influence of pre-sowing tillage systems on the contamination of crops and the yield of spring wheat grain.

The experience was based on the following scheme:

1. Harrowing (control).

2. Harrowing + harrowing.

3. Harrowing + cultivation.

4. Harrowing + cultivation + rolling.

5. Harrowing + rolling.

The soil of the experimental area was sod - slightly podzolic medium loam, the content of hydrolysis nitrogen was 72-78, mobile phosphorus was 220-237 and exchange potassium was $122-131 \mathrm{mg} / \mathrm{kg}, \mathrm{pH}-6.1$. The experience was repeated three times. The total area of the allotment is 60 . The accounting area is $54 \mathrm{~m}^{2}$. The technology of cultivation of spring wheat of the Lada variety was generally accepted for the zone. Pre-sowing tillage for spring wheat was carried out in a field plowed in autumn. Observations, records and analyses were carried out according to the corresponding generally accepted methods.

\section{Results and Discussion}

The importance of solar radiation in plant life is extremely high. Crop yields are created during photosynthesis, when organic matter is formed in green plants from carbon dioxide, water, and minerals. In this case, the energy of the sun's ray is converted into the

\footnotetext{
Corresponding author: aliks06-71@ mail.ru
} 
energy of plant biomass. The share of organic matter formed during photosynthetic processes accounts for about $95 \%$ of the dry matter mass of plants. Crop seeding is an optical photosynthetic system in which the leaves absorb photosynthetic active radiation.

In plants, the main part of the assimilation surface is made up of leaves; it is in them that photosynthesis is carried out. Photosynthesis can also occur in other green parts of plants - stems, spines, green fruits, etc., but their contribution to the overall photosynthesis is small. The dynamics of the leaf area in crops follows a certain pattern. After the emergence of seedlings, the leaf area slowly increases, then the growth rate increases. The maximum leaf surface of the plant is formed at the time of the termination of the formation of lateral shoots and the growth of plants' height. It is believed that at a leaf surface index of 4-5 (40-50 thousand $\mathrm{m}^{2} / \mathrm{ha}$ ), the crop as an optical photosynthetic system works in an optimal mode, absorbing the greatest amount of sunlight.

Analysis of the formation of the leaf area of spring wheat showed that in the tillering phase, the plants had 12.7-12.9 thousand $\mathrm{m}^{2} / \mathrm{ha}$ of epy leaf surface (Table 1 ).

Table 1. Dynamics of the area formation of the spring wheat leaf, thousand $\mathrm{m}^{2} / \mathrm{ha}$, on average for 2019 and 2020

\begin{tabular}{|l|c|c|c|c|c|}
\hline \multirow{2}{*}{$\begin{array}{l}\text { Versions of } \\
\text { the } \\
\text { experiments }\end{array}$} & \begin{tabular}{c} 
Phenological phase \\
\cline { 2 - 6 }
\end{tabular} & $\begin{array}{c}\text { tillerin } \\
\text { elonga } \\
\text { tion }\end{array}$ & earing & $\begin{array}{c}\text { flower } \\
\text { ing }\end{array}$ & $\begin{array}{c}\text { milk } \\
\text { ripene } \\
\text { ss }\end{array}$ \\
\hline $\begin{array}{l}\text { Harrowing } \\
\text { (control) }\end{array}$ & 12.8 & 18.4 & 27.4 & 29.5 & 5.7 \\
\hline $\begin{array}{l}\text { Harrowing } \\
\text { + harrowing }\end{array}$ & 12.7 & 19.6 & 29.5 & 31.5 & 5.8 \\
\hline $\begin{array}{l}\text { Harrowing } \\
\text { + cultivation }\end{array}$ & 12.9 & 19.6 & 30.9 & 33.4 & 6.0 \\
\hline $\begin{array}{l}\text { Harrowing } \\
\text { + cultivation } \\
\text { + rolling }\end{array}$ & 12.8 & 20.2 & 32.0 & 34.4 & 6.1 \\
\hline $\begin{array}{l}\text { Harrowing } \\
\text { + rolling }\end{array}$ & 12.8 & 19.4 & 27.9 & 30.9 & 5.7 \\
\hline
\end{tabular}

In the subsequent periods of development and growth, with the transition of spring wheat to the phase of $t$ stem elongation and earing, there was an intensive increase in its area to 27.4-32.0 thousand $\mathrm{m}^{2} / \mathrm{ha}$, depending on the variant. In the flowering phase, spring wheat formed the maximum leaf area - 29.5-34.4 thousand $\mathrm{m}^{2} / \mathrm{ha}$. At the same time, it was higher on the options harrowing + harrowing and harrowing + cultivation + rolling. After the flowering phase, the area of the leaves of spring wheat, due to their yellowing and dying, gradually decreased. And in the phase of milk ripeness of grain in the ears, it was from 5.7 to 6.1 thousand $\mathrm{m}^{2} / \mathrm{ha}$, depending on the variant. It should be noted that in the variants of the experiment with continuous cultivation in the system of pre-sowing tillage, spring wheat formed more leaf area.

The formation of the crop depends not only on the size of the leaf area, but also on the time of its functioning. Photosynthetic potential combines these indicators. The results of the calculation showed that the photosynthetic potential of spring wheat, depending on the variant, ranged from 1272.8 to 1384.4 thousand $\mathrm{m}^{2} / \mathrm{ha} \times$ day. At the same time, it was higher in the harrowing + cultivation + rolling variant -1384.4 thousand $\mathrm{m}^{2}$ /haxday (Table 2 ).

The net productivity of photosynthesis characterizes the intensity of photosynthesis of the crop and represents the amount of dry mass of plants in grams, which synthesizes $1 \mathrm{~m}^{2}$ of leaf surface per day. Studies have found that the net photosynthetic productivity of spring wheat, depending on the variant, was from 3.2 to 3.5 $\mathrm{g} / \mathrm{m}^{2} \times$ day. Higher net photosynthetic productivity was found in the harrowing + rolling and harrowing + cultivation variants and amounted to $3.5 \mathrm{~g} / \mathrm{m}^{2} \times$ day.

Table 2. Photosynthetic potential and net productivity of spring wheat photosynthesis, on average for 2019 and 2020

\begin{tabular}{|l|c|c|}
\hline \multicolumn{1}{|c|}{$\begin{array}{c}\text { Versions of the } \\
\text { experiments }\end{array}$} & $\begin{array}{c}\text { Photosynthetic } \\
\text { potential, } \\
\text { thousand } \\
\mathrm{m}^{2} / \text { haxday. }\end{array}$ & $\begin{array}{c}\text { Net } \\
\text { photosynthetic } \\
\text { productivity, } \\
\mathrm{g} / \mathrm{m}^{2} \times \text { day. }\end{array}$ \\
\hline $\begin{array}{l}\text { Harrowing } \\
\text { control) }\end{array}$ & 1272.8 & 3.3 \\
\hline $\begin{array}{l}\text { Harrowing }+ \\
\text { harrowing }\end{array}$ & 1316.0 & 3.2 \\
\hline $\begin{array}{l}\text { Harrowing }+ \\
\text { cultivation }\end{array}$ & 1356.7 & 3.5 \\
\hline $\begin{array}{l}\text { Harrowing }+ \\
\text { cultivation }+ \text { rolling }\end{array}$ & 1384.4 & 3.5 \\
\hline $\begin{array}{l}\text { Harrowing }+ \\
\text { rolling }\end{array}$ & 1288.7 & 3.4 \\
\hline
\end{tabular}

Weeds cause great damage to agricultural crops mainly due to the deterioration of their growth and development conditions. Agricultural technologies always provide for the fight against them. In agricultural systems, one of the main methods of weed control is agrotechnical methods. The research has shown that, when using continuous cultivation in the system of presowing tillage, the contamination of spring wheat crops is significantly reduced. So, in the tillering phase of wheat, the number of weeds in the harrowing + cultivation and harrowing + cultivation + rolling variants was 13.9 and $17.2 \mathrm{pcs} . / \mathrm{m}^{2}$, respectively, and in full ripeness -10.7 and $12.0 \mathrm{pcs} . / \mathrm{m}^{2}$. This was, respectively, 21.2-45.1 and 23.6-36.4 \% lower than the infestation of the crops of other variants (Table 3 ).

Table 3. Infestation of spring wheat crops, pcs. $/ \mathrm{m}^{2}$, on average for 2019 and 2020

\begin{tabular}{|c|c|c|c|c|c|c|}
\hline \multirow{3}{*}{$\begin{array}{l}\text { Versions of } \\
\text { the } \\
\text { experiments }\end{array}$} & \multicolumn{3}{|c|}{$\begin{array}{c}\text { The phase of } \\
\text { tillering }\end{array}$} & \multicolumn{3}{|c|}{$\begin{array}{l}\text { The phase of full } \\
\text { ripeness }\end{array}$} \\
\hline & \multirow[b]{2}{*}{ total } & \multicolumn{2}{|c|}{ among them } & \multirow[b]{2}{*}{ total } & \multicolumn{2}{|c|}{ among them } \\
\hline & & $\begin{array}{c}\text { juv } \\
\text { eni } \\
\text { le }\end{array}$ & $\begin{array}{l}\text { per } \\
\text { enn } \\
\text { ial }\end{array}$ & & $\begin{array}{c}\text { juv } \\
\text { enil } \\
\text { e }\end{array}$ & $\begin{array}{l}\text { per } \\
\text { enn } \\
\text { ial }\end{array}$ \\
\hline $\begin{array}{l}\text { Harrowing } \\
\text { (control) }\end{array}$ & 25.3 & 17.5 & 7.8 & 16.8 & 12.4 & 4.4 \\
\hline $\begin{array}{l}\text { Harrowing + } \\
\text { harrowing }\end{array}$ & 21.8 & 16.0 & 5.8 & 16.2 & 11.9 & 4.3 \\
\hline $\begin{array}{l}\text { Harrowing + } \\
\text { cultivation }\end{array}$ & 13.9 & 9.2 & 4.7 & 10.7 & 7.7 & 3.0 \\
\hline $\begin{array}{l}\text { Harrowing + } \\
\text { cultivation + } \\
\text { rolling }\end{array}$ & 17.2 & 12.0 & 5.2 & 12.0 & 8.8 & 3.2 \\
\hline
\end{tabular}




\begin{tabular}{|l|c|c|c|c|c|c|}
\hline $\begin{array}{l}\text { Harrowing }+ \\
\text { rolling }\end{array}$ & 24.8 & 18.5 & 6.3 & 15.7 & 10.9 & 4.8 \\
\hline
\end{tabular}

By the full ripeness phase, the number of weeds on the crops of the experimental variants decreased by 23.1$36.7 \%$. And in general, the nature of the contamination remained the same - the crops of barley were less clogged, in the system of pre-sowing treatment of which continuous cultivation was carried out.

The structure of weed vegetation was analyzed. It was found that in the spring wheat crops, juvenile weeds were mainly found, and there were few perennial weeds. Of the juvenile weeds, there were such species as Stellaria media, Fumaria officinalis, Matricaria inodora, Capsella bursa-pastoris and Thlaspi arvense, and among the perennial weeds - Sónchus arvénsis, Cirsium arvense, Convolvulus arvensis and Taraxacum officinale.

The results of the research showed that the use of cultivation in the system of pre-sowing tillage for spring wheat contributes to a higher grain yield. So, on average, for two years of research, the yield of spring wheat on the harrowing + cultivation + rolling and harrowing + cultivation variants was 2.54 and 2.48 t/ha, respectively, which was higher than the productivity of the other variants by $4.6-9.4 \%$ (Table 4 ).

Table 4. The grain yield of spring wheat, $t / h a$

\begin{tabular}{|c|c|c|c|c|}
\hline \multirow{2}{*}{$\begin{array}{l}\text { Versions of the } \\
\text { experiments }\end{array}$} & \multicolumn{2}{|c|}{ Years } & \multirow{2}{*}{$\begin{array}{c}\text { On } \\
\text { average }\end{array}$} & \multirow{2}{*}{$\begin{array}{c}+- \text { to } \\
\text { control, } \\
\text { t/ha }\end{array}$} \\
\hline & 2019 & 2020 & & \\
\hline $\begin{array}{l}\text { Harrowing } \\
\text { (control) }\end{array}$ & 2.54 & 2.10 & 2.32 & - \\
\hline $\begin{array}{l}\text { Harrowing + } \\
\text { harrowing }\end{array}$ & 2.58 & 2.16 & 2.37 & 0.05 \\
\hline $\begin{array}{l}\text { Harrowing }+ \\
\text { cultivation }\end{array}$ & 2.69 & 2.27 & 2.48 & 0.16 \\
\hline $\begin{array}{l}\text { Harrowing }+ \\
\text { cultivation }+ \text { rolling }\end{array}$ & 2.70 & 2.38 & 2.54 & 0.22 \\
\hline $\begin{array}{l}\text { Harrowing + } \\
\text { rolling }\end{array}$ & 2.56 & 2.12 & 2.34 & 0.12 \\
\hline $\mathrm{SSD}_{05}$ & 0.13 & 0.15 & & \\
\hline
\end{tabular}

The increase in the yield in comparison with the control variant was significant - by 0.22 and 0.16 t/ha. The systems of pre-sowing tillage for spring wheat, consisting of double harrowing and harrowing with rolling, provided a yield of only 2.37 and $2.34 \mathrm{t} /$ ha.

The correlation analysis between the yield and the infestation of spring wheat crops revealed a strong inverse relationship $(r=-0.9)$, and the linear regression equation had the form: $y=104.37-36.08 x$.

The value of the yield of any agricultural crop is always determined by the elements of the crop structure. In grain crops, the main elements of the crop structure are: the number of productive stems per square meter, the number of grains in one ear and the weight of 1000 grains.

The results of the analysis of the structure of the spring wheat crop revealed that the higher grain yield in the harrowing + cultivation + rolling and harrowing + cultivation variants was due to the following higher indicators. The number of productive stems per unit of sown area must be 297 and 290 pieces $/ \mathrm{m}^{2}$, respectively, the number of grains per ear -31.5 and 30.5 pieces, and the weight of 1000 grains -37.2 and $37.3 \mathrm{~g}$ (Table 5). In other variants, the indicators of the elements of the structure of the spring wheat crop were slightly lower.

Table 5. Structure of the yield of spring wheat, on average for 2019 and 2020

\begin{tabular}{|l|c|c|c|c|c|}
\hline $\begin{array}{c}\text { Versions of } \\
\text { the } \\
\text { experiments }\end{array}$ & $\begin{array}{c}\text { Numb } \\
\text { er of } \\
\text { produc } \\
\text { tive } \\
\text { stems, } \\
\text { pcs./m }\end{array}$ & $\begin{array}{c}\text { Produc } \\
\text { tive } \\
\text { of } \\
\text { tillerin } \\
\mathrm{g}\end{array}$ & $\begin{array}{c}\text { Length } \\
\text { of } \\
\text { spike, } \\
\mathrm{cm}\end{array}$ & $\begin{array}{c}\text { The } \\
\text { numbe } \\
\text { rof } \\
\text { kernels } \\
\text { per } \\
\text { spike, } \\
\text { pcs. }\end{array}$ & $\begin{array}{c}\text { Weigh } \\
\text { t of } \\
1000 \\
\text { grains, } \\
\mathrm{g}\end{array}$ \\
\hline $\begin{array}{l}\text { Harrowing } \\
\text { (control) }\end{array}$ & 277 & 1.4 & 7.3 & 30.0 & 36.6 \\
\hline $\begin{array}{l}\text { Harrowing } \\
\text { + harrowing }\end{array}$ & 282 & 1.6 & 7.2 & 29.0 & 37.0 \\
\hline $\begin{array}{l}\text { Harrowing } \\
\text { + cultivation }\end{array}$ & 290 & 1.6 & 7.3 & 30.5 & 37.3 \\
\hline $\begin{array}{l}\text { Harrowing } \\
\text { + cultivation } \\
\text { + rolling }\end{array}$ & 297 & 1.5 & 7.3 & 31.5 & 37.2 \\
\hline $\begin{array}{l}\text { Harrowing } \\
\text { + rolling }\end{array}$ & 280 & 1.5 & 7.2 & 30.0 & 37.1 \\
\hline
\end{tabular}

The quality of grain of agricultural crops is characterized by a number of characteristics, caused by their varietal characteristics, technology of cultivation and harvesting, storage and processing of grain, etc. Research has established that the system of pre-sowing tillage, as an element of agricultural technology of culture, affects the quality of spring wheat grain. Thus, the protein content in wheat grain ranged from $11.05 \%$ - in the control to $11.80 \%$ - in the variant, in the system of pre-sowing treatment of which harrowing and cultivation were carried out. It was found that when using cultivation, the protein content of wheat grain increased by $0.17-0.75 \%$ (Table 6).

Table 6. Quality of spring wheat grain, on average for 2019 and 2020

\begin{tabular}{|l|c|c|c|c|c|c|c|}
\hline \multirow{2}{*}{$\begin{array}{c}\text { Versions of } \\
\text { the } \\
\text { experiments }\end{array}$} & $\mathrm{N}$ & $\mathrm{P}$ & $\mathrm{K}$ & $\begin{array}{c}\text { pro } \\
\text { tein }\end{array}$ & $\begin{array}{c}\text { Conte } \\
\mathrm{nt}, \%\end{array}$ & $\begin{array}{c}\text { quali } \\
\text { ty } \\
\text { grou } \\
\mathrm{p}\end{array}$ & $\begin{array}{c}\text { Vitre } \\
\text { ous, } \\
\%\end{array}$ \\
\hline $\begin{array}{l}\text { Harrowing } \\
\text { control) }\end{array}$ & 1.94 & 1.33 & 0.56 & 11.0 & 24.7 & $\mathrm{I}$ & 52.1 \\
\hline $\begin{array}{l}\text { Harrowing }+ \\
\text { harrowing }\end{array}$ & 1.95 & 1.25 & 0.56 & 11.1 & 24.7 & $\mathrm{I}$ & 51.8 \\
\hline $\begin{array}{l}\text { Harrowing }+ \\
\text { cultivation }\end{array}$ & 2.07 & 1.43 & 0.58 & 11.8 & 25.4 & $\mathrm{I}$ & 54.4 \\
\hline $\begin{array}{l}\text { Harrowing }+ \\
\text { cultivation }+ \\
\text { rolling }\end{array}$ & 2.06 & 1.31 & 0.53 & 11.7 & 25.0 & $\mathrm{I}$ & 53.2 \\
\hline $\begin{array}{l}\text { Harrowing }+ \\
\text { rolling }\end{array}$ & 2.03 & 1.32 & 0.59 & 11.5 & 24.8 & $\mathrm{I}$ & 51.7 \\
\hline
\end{tabular}

In assessing the technological qualities of spring wheat grain intended for milling and baking purposes, much attention is paid to the content and quality of gluten in it, as well as its vitreous content. The results of laboratory studies showed that the higher content of gluten in wheat grain was when using cultivation in the 
pre-sowing treatment system, on the variants harrowing + cultivation and harrowing + cultivation + rolling, and amounted to 25.4 and $25.0 \%$, respectively.

According to the quality of gluten, wheat grain of all variants was obtained in the first group. The vitreous content of the grain of the culture, depending on the variant of the experiment, ranged from 51.7 to $54.4 \%$. At the same time, the grain of wheat cultivated with the use of cultivation in preparing the soil for sowing was also more glassy - 53.2-54.4\%.

Improving production efficiency is a complex and challenging task. The agronomic efficiency of the use of certain techniques for the cultivation of agricultural crops reflects the effect of the studied factors on the value of their yield and its quality.

However, a more complete assessment can be obtained only when determining the economic feasibility of the agricultural practices used. It is well known that the agricultural practices used in agronomic practice are economically effective when the cost of the crop increase pays for all the costs associated with carrying out field work on the cultivation of the crop, as well as with harvesting, transportation, and part-time work of the additional crop of the main and by-products.

The economic efficiency of the cultivation of agricultural crops is based on obtaining the maximum output per unit of sown area at the minimum cost. It is determined by a system of economic indicators, among which the following characteristics can be distinguished: production costs per 1 ha of sowing, gross harvest, net income and profitability of production.

The results of calculations of economic efficiency showed that the cultivation of spring wheat in the years of research was profitable (Table 7).

Table 7. Economic efficiency of spring wheat cultivation, on average for 2019 and 2020

\begin{tabular}{|l|c|c|c|c|}
\hline $\begin{array}{c}\text { Versions of the } \\
\text { experiments }\end{array}$ & $\begin{array}{c}\text { Crop } \\
\text { value, } \\
\text { rubles/ha }\end{array}$ & $\begin{array}{c}\text { Productio } \\
\text { n costs, } \\
\text { rubles/ha }\end{array}$ & $\begin{array}{c}\text { Net } \\
\text { income, } \\
\text { rubles/ha }\end{array}$ & $\begin{array}{c}\text { Profitab } \\
\text { ility, } \\
\%\end{array}$ \\
\hline $\begin{array}{l}\text { Harrowing } \\
\text { control) }\end{array}$ & 16240.00 & 9279.96 & 6960.04 & 75.0 \\
\hline $\begin{array}{l}\text { Harrowing + } \\
\text { harrowing }\end{array}$ & 16590.00 & 9477.50 & 7112.50 & 75.0 \\
\hline $\begin{array}{l}\text { Harrowing + } \\
\text { cultivation }\end{array}$ & 17360.00 & 9809.66 & 7550.34 & 76.9 \\
\hline $\begin{array}{l}\text { Harrowing + } \\
\text { cultivation }+ \\
\text { rolling }\end{array}$ & 17780.00 & 9810.05 & 7969.95 & 81.2 \\
\hline $\begin{array}{l}\text { Harrowing }+ \\
\text { rolling }\end{array}$ & 16380.00 & 9487.47 & 6892.53 & 72.6 \\
\hline
\end{tabular}

Production costs for the cultivation of spring wheat in the experiment depended on the methods of presowing tillage for this crop and ranged from 9279.96 rubles/ha (on the control) to 9810.05 rubles/ha (on the harrowing + cultivation + rolling option). The level of net income is always affected by both production costs and the cost of products produced.

A higher net income was obtained when harrowing, cultivation and rolling were used in the system of presowing tillage - 7969.95 rubles/ha. On the other variants, it was 5.3-13.6\% lower. Calculations revealed that the production of spring wheat grain was economically profitable. The profitability, depending on the option, ranged from 72.6 to $81.2 \%$. At the same time, the harrowing + cultivation + rolling option provided higher profitability.

\section{Conclusion}

Thus, the results of the conducted researches allow us to draw the following conclusions:

1. The use of continuous cultivation in the system of pre-sowing tillage is an effective method in the fight against weeds - the infestation of spring wheat crops decreased by $21.2-45.1 \%$.

2. A higher yield of spring wheat and a significant increase in yield were obtained when using cultivation in the system of pre-sowing tillage: on the variants harrowing + cultivation + rolling and harrowing + cultivation. The grain yield was 2.54 and $2.48 \mathrm{t} / \mathrm{ha}$, respectively.

3. Methods of pre-sowing tillage affect the quality of spring wheat grain. The use of cultivation in the system of pre-sowing tillage increased the protein content of the grain by $0.17-0.75 \%$, the gluten content - by $0.2-0.7 \%$ and the vitreous content - by 1.1-2.7\%.

\section{References}

1. V.I. Makarov, V.V. Glushkov, Methods of tillage for spring barley, Agriculture, 6 (2010)

2. R.D. Armstrong, G. Millar, N.V. Halpin, D.J. Reid, J. Standley, Using zero tillage, fertilisers and legume rotations to maintain productivity and soil fertility in opportunity cropping systems on a shallow Vertosol, Australian Journal of Experimental Agriculture, 43 (2003)

3. M.R. Akhmetzyanov, I.P. Talanov, Influence of basic tillage systems and nutrition backgrounds on crop productivity of the field crop rotation link, Achievements of science and technology of the agroindustrial complex, 5 (2019)

4. R. Lal, No-tillage effects on soil conditions and maize production in Western Nigeria, Plant and Soil, 40 (1973)

5. Yu.I. Mitrofanov, L.I. Petrova, M.V. Gulyaev, N.K. Pervushina, Pre-sowing soil cultivation with different methods of sowing cereals, Agriculture, 6 (2020)

6. R. Moussadek, R. Mrabet, R. Dahan, A. Zouahri, M.E. Mourid, E.V. Ranst, Tillage system affects soil organic carbon storage and quality in central Morocco, Applied and Environmental Soil Science, 1-8 (2014)

7. S.I. Novoselov, A.N. Kuzminykh, R.V. Eremeev, The influence of fallow types and methods of primary tillage on soil fertility and productivity crop rotation, Fertility, 6 (2019)

8. X. Yin, T.J. Vyn, Residual effects of potassium placement and tillage systems for corn on subsequent no-till soybean, Agronomy Journal, 94 (2002)

9. A.N. Kuzminykh, The system of pre-sowing tillage 
and the yield of spring barley, Vestnik of Mari state University, 1 (2020)

10. R. Khan, S. Biswas, C. Kumar Kundu, K. Jana, Effect of Conservation Tillage on Yield and Economics of Fodder Crops, International Journal of Environment and Climate Change, 10 (2020) 